\title{
Effect of root pruning on competitive ability in Chinese jujube tree
}

\author{
Shou-jun YANG ${ }^{1}$, Zhen-yu Du ${ }^{2}$, Yan Yu ${ }^{1}$, Yuan-yuan $C_{H E}{ }^{1}$, Chun-hong YUAN ${ }^{1}$, Shang-jun XING ${ }^{2 *}$
}

1 Yantai Inst., China Agric. Univ., 264670, Yantai, Shandong, P.R. China

2 Shandong For. Acad., 250014, Jinan, Shandong, P. R. China, xingsj_1126@126.com

${ }^{*}$ Correspondence and reprints

Received 10 August 2011 Accepted 27 January 2012

Fruits, 2012, vol. 67, p. 429-437 (c) 2012 Cirad/EDP Sciences All rights reserved DOI: $10.1051 /$ fruits/2012038 Www.fruits-journal.org

RESUMEN ESPAÑOL, p. 437

\section{Effect of root pruning on competitive ability in Chinese jujube tree.}

Abstract-Introduction. The Chinese jujube tree always presents some unfavorable performances because its vegetative growth is very vigorous. Our study was conducted to apply root pruning to test whether it can effectively inhibit the vigorous vegetative growth by regulating the competitive ability of the root system for water and nutrients. Materials and methods. For our experiment, roots were cut at three different distances from the trunk (light, moderate and severe root pruning) on both inter-row sides of jujube trees to the depth of $20 \mathrm{~cm}$. Roots of control jujube trees were not pruned. Then we determined for three years the competitive indicators of Chinese jujube trees including the length, number and thickness of primary branches; photosynthetic characteristics and nutrient concentrations of leaves; hormone contents in the jujube head, flower number and fruiting percentage, yield, and fruit quality. Results and discussion. In the early stage after root treatment, root pruning decreased lots of indicators such as concentrations of nitrogen, phosphorus, and potassium in leaves, photosynthesis, transpiration, stomatal conductance, and intercellular $\mathrm{CO}_{2}$ concentration of leaves, relative to the same indicators as the control group. With the gradual emergence of new roots, these indexes appeared to have adverse patterns with respect to those in the early stage after root pruning. Compared with the control, root pruning significantly decreased the length and number of primary branches and flower number, but thickened primary branches, enhanced fruiting percentage and increased the amount of ethylene release of the jujube head in the whole experiment. Fruit quality was improved with root pruning, as indicated by increases in vitamin $\mathrm{C}$ and total sugar and a decrease in titrable acidity. No effects of root pruning were noticed on yield. From our results, we conclude that the removal of the root system at a distance of three times the trunk diameter (severe pruning) from the trunk is the most effective in regulating the competitive ability of the Chinese jujube tree.

China / Ziziphus / root pruning / plant response / performance testing / agronomic characters / fruits / quality

\section{Effet de la taille des racines sur les performances du jujubier chinois.}

Résumé - Introduction. Le jujubier chinois présente toujours certaines performances désavantageuses du fait de sa croissance végétative très vigoureuse. Notre étude a été menée pour tester la taille des racines afin de vérifier si elle peut freiner efficacement la croissance végétative en régulant la compétitivité du système racinaire pour l'eau et les nutriments. Matériel et méthodes. Pour notre expérimentation, les racines de jujubiers chinois ont été coupées à trois distances différentes à partir du tronc (taille légère, modérée et sévère des racines), de chaque côté entre les rangs de jujubiers, à $20 \mathrm{~cm}$ de profondeur. Les racines des jujubiers témoins n'ont pas été taillées. Nous avons ensuite suivi pendant trois années certains indicateurs de compétitivité du jujubier chinois, dont la longueur, le nombre et l'épaisseur des branches primaires ; les caractéristiques photosynthétiques et les concentrations en éléments nutritifs des feuilles; les teneurs en hormones dans le haut des arbres ; le nombre de fleurs et le taux de fructification, ainsi que le rendement et la qualité des fruits. Résultats et discussion. Au début, après traitement des racines, la taille des racines a induit la diminution de nombreux indicateurs tels que les concentrations en azote, en phosphore, en potassium des feuilles, ainsi que la photosynthèse, la transpiration, la conductance stomatique, la concentration en $\mathrm{CO}_{2}$ intercellulaire des feuilles, par rapport aux mêmes indicateurs mesurés sur les arbres du groupe témoin. Avec l'émergence progressive de nouvelles racines, ces indices ont eu un comportement inverse par rapport à ceux mesurés à ce stade précoce faisant suite à la taille des racines. Par rapport aux arbres témoins, la taille des racines a diminué significativement la longueur et le nombre de branches primaires et le nombre de fleurs, mais elle a induit un épaississement des branches primaires, une amélioration du taux de fructification et une augmentation de la quantité d'éthylène libérée par la tête des arbres. La qualité des fruits a été améliorée avec la taille des racines : augmentation de la teneur en vitamine $\mathrm{C}$ et des sucres totaux et diminution de l'acidité titrable. La taille des racines n'a pas eu d'effets sur le rendement. Nous déduisons de nos résultats que la suppression du système racinaire à une distance du tronc égale à trois fois son diamètre (taille sévère) est le traitement le plus efficace pour réguler la compétitivité du système racinaire du jujubier chinois.

Chine / Ziziphus / taille des racines / réponse de la plante / contrôle de performance / caractère agronomique / fruits / qualité 


\section{Introduction}

It is well known that fruit trees will show some unfavorable performances such as lower light penetration, fruit percentage, yield and fruit quality, higher costs of pruning and pest control [1], and emergence of biennial bearing of fruits, if their vegetative and reproductive growth is not balanced. The main reason is that the competitive abilities of trees during their vegetative and reproductive growth are not harmonized.

Plant competitive ability depends on such factors as plant height, number of branches, the root system [2] and physiological indexes consisting of photosynthesis, transpiration, stomatal conductance, intercellular $\mathrm{CO}_{2}$ concentration, and so on. Among them, the root system is dominant because it serves a multitude of functions in the plant, including anchorage, provision of nutrients and water, and production of exudates with growth-regulatory properties [3]. Theoretically speaking, a large root system is more advantageous to the plant in acquiring water and nutrients than a small root system [4], but Passioura argued that the root system of plants might be unnecessarily large [5], in accordance with the conclusion of Zhang and Zhang that spring wheat with a large root system is more competitive but has a smaller grain yield than that with a small root system [6]. Obviously, a large root system can result in excessive soil water and nutrient consumption. This means that a large root system can easily cause plant vegetative growth to be vigorous.

'Chinese' jujube is an elite variety of $\mathrm{Ziz}$ iphus jujuba Miller, but the vegetative growth of Chinese jujube trees is very vigorous. That is, their competitive abilities in vegetative growth are greater than in reproductive growth. Generally, many methods are available to coordinate the balance of both in deciduous fruit tree species [7], including shoot pruning, bark girdling, scoring and fruit thinning. However, these treatments may severely weaken tree vigor, reduce the harvest index and increase the risks of epiphytes and physiological diseases. In order to effectively inhibit the vigorous vegetative growth, perhaps regulating the competitive ability of the root system for water and nutrients in the growing development is a better choice.

Root pruning was once and is still now widely used in Europe to reduce fruit tree size and promote flower bud initiation and fruiting [8]. It can not only reduce shoot extension, leaf number and area per plant, but also inhibit photosynthesis and transpiration [9]. Specifically, root pruning destroys the old growth balances of trees and changes their assimilation abilities, nutrient distributions and hormone levels. The combined action of these elements may cause different effects on growth and fruit quality [10].

Therefore, our study was targeted at optimizing the root system by root pruning and testing how the competitive indicators of Chinese jujube trees change by reducing the root system.

\section{Materials and methods}

\subsection{Plant material and growth conditions}

The experimental site of our experiment was located in the Yellow River Delta, China. The field experiment was carried out in the Chinese jujube orchard, Binzhou city, Shandong province $\left(37.22^{\circ} \mathrm{N}, 108.02^{\circ} \mathrm{E}\right)$ between 2008 and 2010. Six-year-old jujube trees were used and the rows were planted $3 \mathrm{~m}$ apart with plant spacing of $3 \mathrm{~m}$ within each row. The mean trunk diameter was $7.5 \mathrm{~cm}$. The height of trees ranged from $2.1 \mathrm{~m}$ to $2.5 \mathrm{~m}$.

\subsection{Experimental design and root pruning treatments}

The experiment involved a randomized, complete block design with three replications. Each block consisted of 10 trees arrayed in the same row. Prior to bud break, four treatments were applied to the examined trees on April 26, 2008: (1) control, with intact root system; (2) light, removing the root system at a distance of seven times the 
Table I.

The effects of different root pruning intensities on the length, thickness and number of primary branches per tree (2008-2010) of Chinese jujube. Root pruning treatments: control, without root pruning; light, root pruning $52.5 \mathrm{~cm}$ from the trunk; moderate, root pruning at $37.5 \mathrm{~cm}$; severe, root pruning at $22.5 \mathrm{~cm}$.

\begin{tabular}{lccccccccc} 
Root pruning treatment & \multicolumn{3}{c}{$\begin{array}{c}\text { Length } \\
(\mathrm{cm})\end{array}$} & \multicolumn{3}{c}{$\begin{array}{c}\text { Thickness } \\
(\mathrm{cm})\end{array}$} \\
\cline { 2 - 11 } & 2008 & 2009 & 2010 & 2008 & 2009 & 2010 & 2008 & 2009 & 2010 \\
Control & $31.22 \mathrm{a}$ & $35.40 \mathrm{a}$ & $30.72 \mathrm{a}$ & $0.51 \mathrm{a}$ & $0.54 \mathrm{~b}$ & $0.75 \mathrm{~b}$ & $98.50 \mathrm{a}$ & $63.67 \mathrm{a}$ & $107.02 \mathrm{a}$ \\
Light & $29.33 \mathrm{ab}$ & $33.33 \mathrm{ab}$ & $30.01 \mathrm{a}$ & $0.52 \mathrm{a}$ & $0.53 \mathrm{~b}$ & $0.77 \mathrm{~b}$ & $96.12 \mathrm{a}$ & $54.00 \mathrm{~b}$ & $101.94 \mathrm{a}$ \\
Moderate & $25.51 \mathrm{ab}$ & $31.33 \mathrm{~b}$ & $30.15 \mathrm{a}$ & $0.51 \mathrm{a}$ & $0.53 \mathrm{~b}$ & $0.88 \mathrm{a}$ & $89.29 \mathrm{~b}$ & $49.00 \mathrm{c}$ & $64.67 \mathrm{~b}$ \\
Severe & $22.50 \mathrm{~b}$ & $29.67 \mathrm{c}$ & $30.04 \mathrm{a}$ & $0.49 \mathrm{~b}$ & $0.56 \mathrm{a}$ & $0.92 \mathrm{a}$ & $86.56 \mathrm{~b}$ & $43.00 \mathrm{~d}$ & $69.67 \mathrm{~b}$
\end{tabular}

The results are expressed as means $(n=3)$ and different letters in the same column indicate significant difference at the $5 \%$ level.

trunk diameter from the trunk: $52.5 \mathrm{~cm}$; (3) moderate, removing the root system at a distance of five times the trunk diameter from the trunk: $37.5 \mathrm{~cm}$; (4) severe, removing the root system at a distance of three times the trunk diameter from the trunk: $22.5 \mathrm{~cm}$. Roots were cut with a sharp spade at different distances from the trunk on both inter-row sides of jujube trees to the depth of $20 \mathrm{~cm}$. The treated trees were managed in accordance with routine care.

\subsection{Data collection and determination methods}

The length, thickness and number of primary branches were measured and counted in early June every year. The samplings of mature leaves, jujube heads and the determinations of photosynthesis, transpiration, stomatal conductance and intercellular $\mathrm{CO}_{2}$ concentration were carried out in early June and early October every year. Flower number and fruit number were counted in early July and late July every year, respectively. The sample of fruits was picked in early October every year.

Total N, P and K concentrations in leaves were determined using the method of $\mathrm{Lu}$ [11]. The yield of each treatment was recorded in kilograms. Fruit quality was analyzed for vitamin C content by titration [12], for total sugar content with a photometer and for titrable acid content by titration [11]. Photosynthesis, transpiration, stomatal conductance and intercellular $\mathrm{CO}_{2}$ concentra- tion were detected using a CB-1102 Portable Photosynthesis System from 9:00 to 11:00 AM with three replications for each treatment. Twenty grams of jujube head were put into a container and then sealed for $16 \mathrm{~h}$ for determination of the quantity of ethylene (ETIH) release. The analysis was carried out by a Tsushima gas chromatography system on a GC-9A. Auxin [(indole-3-acetic acid (IAA)] was analyzed using the method of Vysotskaya et al. [13].

\subsection{Statistical analysis}

All experiments were repeated as indicated. Values presented are means. The effects of the treatments were tested by one-way analysis of variance (ANOVA). Means were compared among the treatments using the LSD (least significant difference) test at the 0.05 probability level.

\section{Results}

\subsection{The length, thickness and number of primary branches}

Compared with the control, the length and number of primary branches were obviously reduced in the whole experiment and the thickness decreased by $3.9 \%$ in 2008 , but increased by $3.7 \%$ in 2009 and by $22 \%$ in 2010 after severe root pruning (table I). The 
Figure 1.

The effects of root pruning on IAA concentration and ethylene release in the jujube head (Chinese jujube trees, 20082010). Root pruning treatments: control, without root pruning; light, root pruning $52.5 \mathrm{~cm}$ from the trunk; moderate, root pruning at $37.5 \mathrm{~cm}$; severe, root pruning at $22.5 \mathrm{~cm}$. The results are expressed as means $(n=3)$.

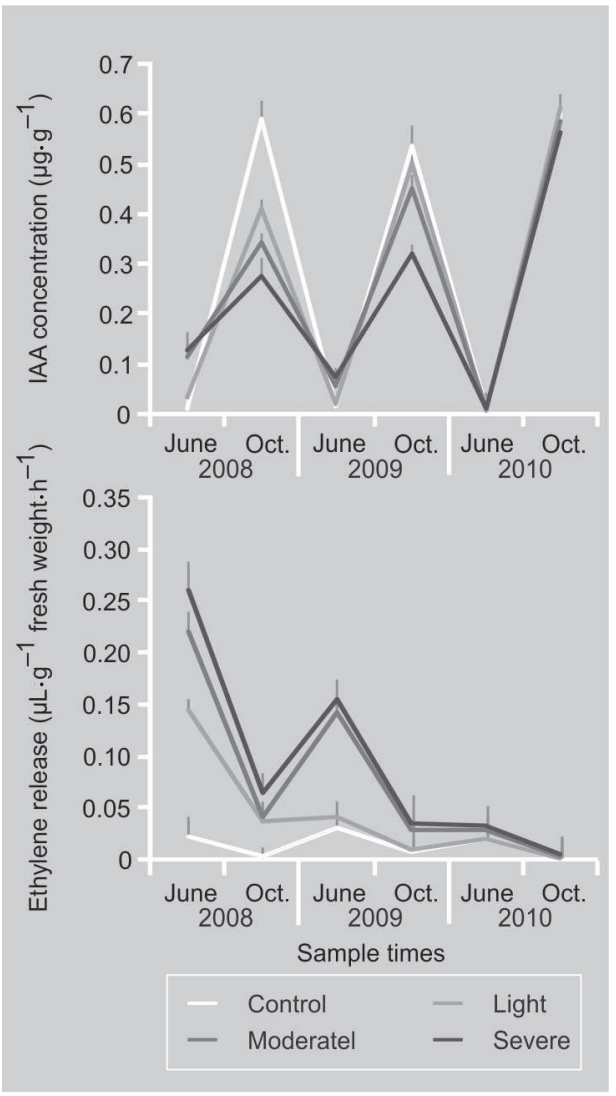

effects of root excision on primary branch growth gradually declined with the increase in pruning distance from the trunk. No significant difference was noticed between light root pruning and the control.

\subsection{IAA content and ethylene release quantity of the jujube head}

The IAA contents of jujube heads under severe and moderate root pruning were higher than those of the control in early June in 2008 (figure 1). From early October in 2008 , they were always lower in comparison with the control. No sharp difference was found between the light treatment and the control. From the beginning of root pruning in 2008 up to the harvest season in 2010, ethylene release quantities of jujube heads of severe and moderate treatments always increased as opposed to the control. The light treatment only had a distinctly higher quantity than that of control once in 2008 and no differences were noticed during the subsequent 2 years.

\subsection{Total $\mathrm{N}, \mathrm{P}$ and $\mathrm{K}$ concentrations in the leaves}

Total nitrogen concentrations of leaves in severe and moderate treatments were lower relative to the control (figure 2). Diversities among treatments were especially drastic in the current year of root excision. Compared with the control, phosphorus and potassium concentrations of the severe and moderate pruned trees decreased in both 2008 and 2009 but increased in 2010. Root pruning of different intensities had entirely different effects on the mineral nutrient status of Chinese jujube trees (figure 2).

\subsection{Photosynthetic characteristics of jujube leaves}

The photosynthesis, transpiration, stomatal conductance and intercellular $\mathrm{CO}_{2}$ concentration of leaves in the severe and moderate treatments were significantly lower in early June in 2008 but higher in the following two years, than those of the control (figure 3). The light treatment had no difference from the control. It is clear that root pruning could improve photosynthetic characteristics of jujube trees.

\subsection{Flower number, fruiting percentage and yield}

Root pruning significantly affected the flower number, fruiting percentage and yield (table II). The yield of Chinese jujube was enhanced by root pruning, while not reaching a statistically significant level during the entire experiment. In the three experimental years, flower number under severe root pruning was decreased by $74 \%$, $71 \%$ and $46 \%$ but fruiting percentage was increased by $50 \%, 178 \%$ and $147 \%$, respectively, in comparison with the control. Jujube trees of the moderate treatment had the same trend as the severe treatment, but variations with the control declined. There was no statistically significant treatment 
effect between the light root pruning treatment and the control.

\subsection{Fruit quality}

The contents of vitamin C and total sugar in fruits were increased by root pruning in the study (table III). No obvious effects of root pruning on titrable acid contents were seen, although they increased to some extent in the first fruiting year. In the following two years, none but the severe treatment had a significant decrease in titrable acid content in comparison with the control (table III).

\section{Discussion}

Primary branches are the new ones sprouting in the springtime. Their number and length are indicators of whether the competitive abilities of jujube trees in vegetative growth are strong. The experimental results indicated that severe root pruning of jujube trees could effectively decrease the length and number of primary branches. This meant there was a serious reduction of growth [14]. These effects were also reported by Schupp and Ferree [15]. The reason probably is that root pruning inevitably decreases the root volume and photosynthates are lavishly transported into the underground plant organs to stimulate the activity of the roots, which in its turn stimulates shoot growth by improving their nutrient supply [16]. On the contrary, restriction of root growth results in inhibition of shoot growth [17].

Plant roots serve as a site for provision of nutrients and water. Compared with the control, total N, P and $\mathrm{K}$ concentrations in leaves of trees submitted to severe and moderate root pruning treatments were differently decreased because root pruning reduced the large size of the root system and hence lowered competitive ability for water and mineral uptake [18], which resulted in lowered N, P and K concentrations in leaves. With the appearance of new roots, variations among treatments became gradually closer to each other.

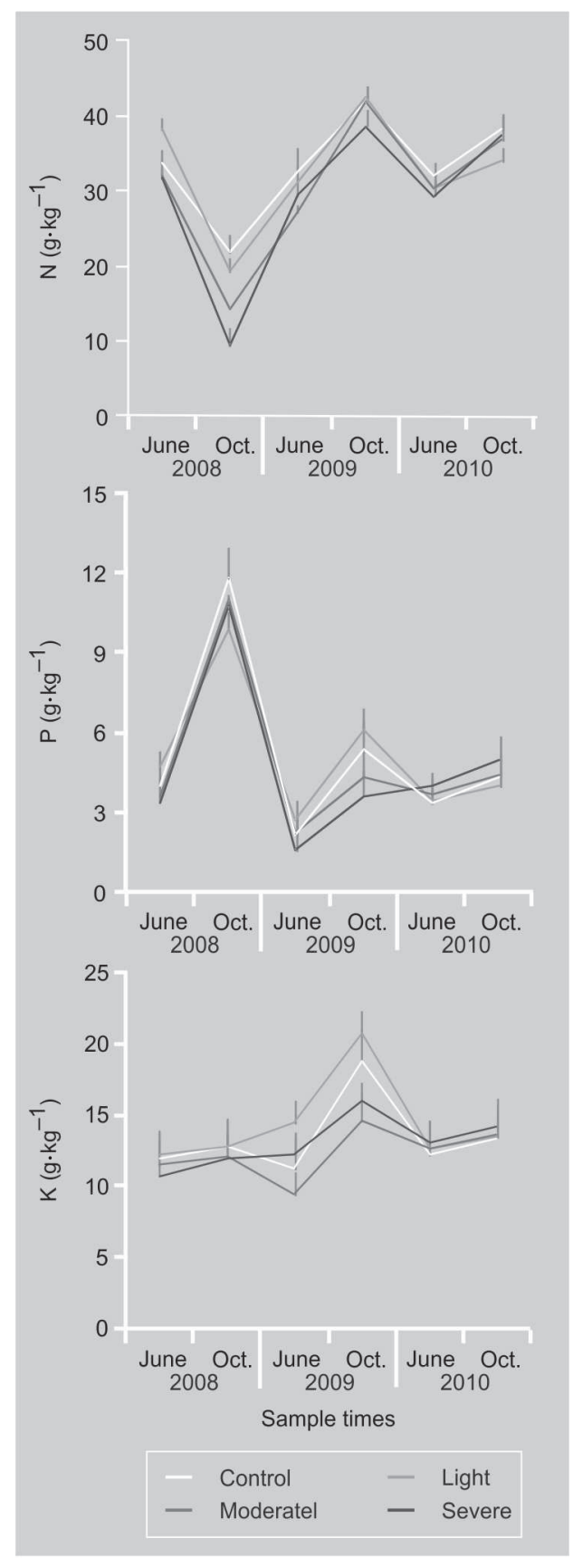

Figure 2.

The effects of root pruning on total $\mathrm{N}, \mathrm{P}$ and $\mathrm{K}$ concentrations in jujube leaves. (Chinese jujube trees, 2008-2010). Root pruning treatments: control, without root pruning; light, root pruning $52.5 \mathrm{~cm}$ from the trunk; moderate, root pruning at $37.5 \mathrm{~cm}$; severe, root pruning at $22.5 \mathrm{~cm}$. The results are expressed as means $(n=3)$.
The data demonstrated that photosynthesis with a severe degree of root pruning was evidently lower than that of the control in early June in 2008, consistent with other reports showing that a damaged root system could lead to reduced photosynthesis due to an overall reduced water and nutrient 
Figure 3.

The effects of root pruning on photosynthesis, transpiration, stomatal conductance and intercellular $\mathrm{CO}_{2}$ concentration of jujube leaves (Chinese jujube trees, 2008-2010). Root pruning treatments: control, without root pruning; light, root pruning $52.5 \mathrm{~cm}$ from the trunk; moderate, root pruning at $37.5 \mathrm{~cm}$; severe, root pruning at $22.5 \mathrm{~cm}$. The results are expressed as means $(n=3)$.
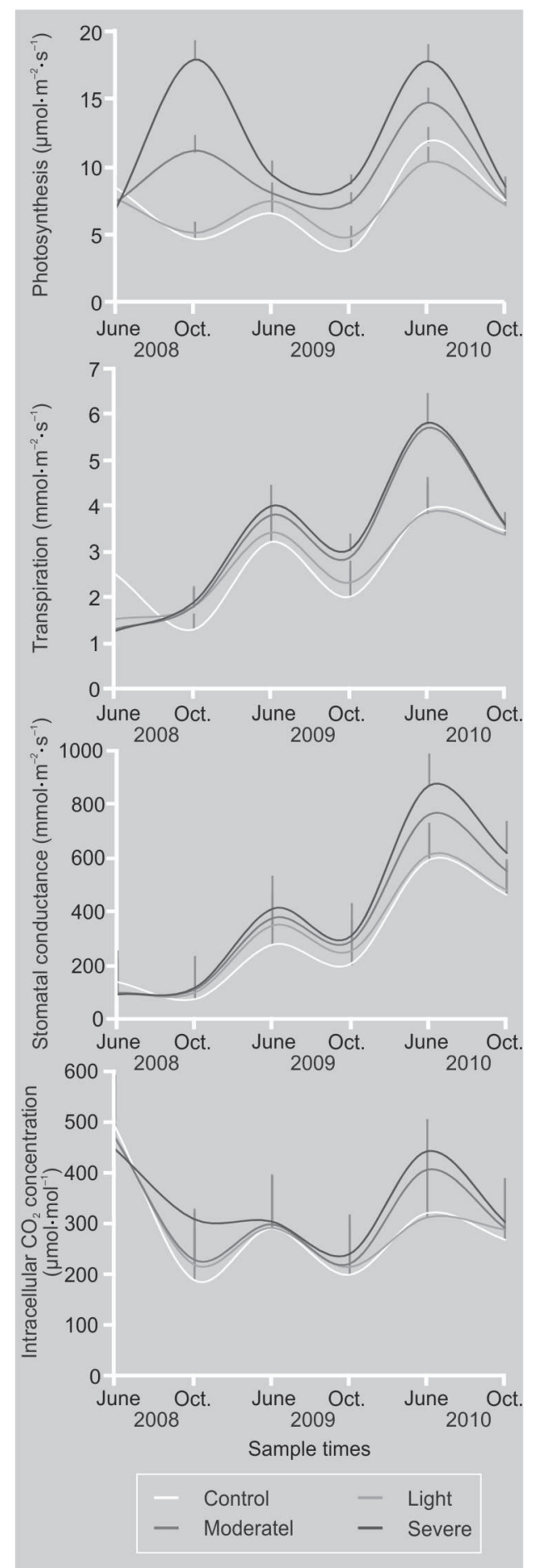

uptake capacity, and a lowered sink capacity for photosynthates [19]. Stomata are most sensitive to water deficit and respond rapidly to the change in water, allowing trees to balance water loss and uptake [20]. Root pruning certainly decreased water uptake of roots and therefore resulted in stomata shutting, which also caused stomatal conductance, intercellular $\mathrm{CO}_{2}$ concentration and transpiration to be less than those of the control in the early growing stage as roots were pruned. It has been shown that photosynthesis, stomatal conductance, intercellular $\mathrm{CO}_{2}$ concentration and transpiration of treated trees increased when newly formed roots emerged capable of greater water and resource uptake than older roots [21].

Ethylene can restrain elongation of cells [22]. Ethylene release of the jujube head markedly increased in the early stage after root pruning, which was the probable reason for inhibition of elongation of primary branches. Since IAA is known to be involved in the initiation of lateral roots [23], the increase in IAA content of the jujube head was possibly because treated jujube trees accelerated the export of IAA in the overground organs to roots for initiation of lateral roots. As lateral roots emerged, the IAA content greatly decreased, as observed in early October in 2008, probably because the overground organs of treated trees could not be restored to the relevant status associated with a rapidly enlarged root system.

The number of flowers per tree decreased while fruiting percentage increased (table II). It is clear that the competitive ability for nutrients of the jujube tree was balanced, occurring with vegetative growth inhibition and reproductive growth improvement. Despite the changes as mentioned above, no significant differences were observed in fruit yield in this study, in agreement with the report of Andersen [24], according to which root pruning had little effect on fruit set, fruit size and yield. The experimental data also demonstrated that root pruning increased total sugar content in fruit, beneficial for desiccation tolerance [25], and fruit quality was the best in the third fruiting year.

\section{Conclusion}

On the basis of different performance indicators, the conclusion can be drawn that 
Table II.

The effects of different root pruning intensities on the flower number, fruiting percentage and yield per tree (2008-2010) of Chinese jujube. Root pruning treatments: control, without root pruning; light, root pruning $52.5 \mathrm{~cm}$ from the trunk; moderate, root pruning at $37.5 \mathrm{~cm}$; severe, root pruning at $22.5 \mathrm{~cm}$.

\begin{tabular}{|c|c|c|c|c|c|c|c|c|c|}
\hline \multirow[t]{2}{*}{$\begin{array}{l}\text { Root pruning } \\
\text { treatment }\end{array}$} & \multicolumn{3}{|c|}{ Flower number } & \multicolumn{3}{|c|}{$\begin{array}{l}\text { Fruit percentage } \\
\text { (\%) }\end{array}$} & \multicolumn{3}{|c|}{$\begin{array}{l}\text { Yield } \\
(\mathrm{kg})\end{array}$} \\
\hline & 2008 & 2009 & 2010 & 2008 & 2009 & 2010 & 2008 & 2009 & 2010 \\
\hline Control & 49378 a & $51640 \mathrm{a}$ & $85315 a$ & $2.75 \mathrm{~d}$ & $3.22 \mathrm{~d}$ & $3.07 \mathrm{~d}$ & $12.97 \mathrm{a}$ & $14.55 \mathrm{a}$ & $13.85 \mathrm{a}$ \\
\hline Light & $48035 \mathrm{a}$ & $49216 a$ & $84418 a$ & $3.76 \mathrm{c}$ & $4.39 c$ & $3.94 \mathrm{c}$ & $14.05 \mathrm{a}$ & $14.38 \mathrm{a}$ & $13.55 \mathrm{a}$ \\
\hline Moderate & $18135 b$ & $22463 b$ & $61045 b$ & $4.54 \mathrm{a}$ & $5.61 \mathrm{~b}$ & $5.12 b$ & $14.32 \mathrm{a}$ & $14.87 \mathrm{a}$ & $13.93 \mathrm{a}$ \\
\hline Severe & $12767 \mathrm{c}$ & $14983 \mathrm{c}$ & $46039 \mathrm{c}$ & $4.13 \mathrm{~b}$ & $8.94 \mathrm{a}$ & $7.57 \mathrm{a}$ & $13.86 \mathrm{a}$ & $15.42 \mathrm{a}$ & $14.07 \mathrm{a}$ \\
\hline
\end{tabular}

The results are expressed as means $(n=3)$ and different letters in the same column indicate significant difference at the $5 \%$ level.

\section{Table III.}

The effects of different root pruning intensities on the quality of Chinese jujube fruits (2008-2010). Root pruning treatments: control, without root pruning; light, root pruning $52.5 \mathrm{~cm}$ from the trunk; moderate, root pruning at $37.5 \mathrm{~cm}$; severe, root pruning at $22.5 \mathrm{~cm}$.

\begin{tabular}{|c|c|c|c|c|c|c|c|c|c|}
\hline \multirow[t]{2}{*}{$\begin{array}{l}\text { Root pruning } \\
\text { treatment }\end{array}$} & \multicolumn{3}{|c|}{$\begin{array}{c}\text { Vitamin C } \\
\left(\mathrm{mg} \cdot 100 \mathrm{~g}^{-1}\right)\end{array}$} & \multicolumn{3}{|c|}{$\begin{array}{c}\text { Total sugar } \\
\text { (\%) }\end{array}$} & \multicolumn{3}{|c|}{$\begin{array}{c}\text { Titrable acid } \\
(\%)\end{array}$} \\
\hline & 2008 & 2009 & 2010 & 2008 & 2009 & 2010 & 2008 & 2009 & 2010 \\
\hline Control & $155.319 \mathrm{c}$ & $137.351 \mathrm{~d}$ & $313.238 \mathrm{c}$ & $14.012 \mathrm{~d}$ & $25.081 \mathrm{c}$ & $27.755 \mathrm{~b}$ & $0.461 \mathrm{a}$ & $0.469 \mathrm{~b}$ & $0.415 a$ \\
\hline Light & $158.124 \mathrm{c}$ & $147.419 \mathrm{c}$ & $315.996 \mathrm{c}$ & $14.886 \mathrm{c}$ & 24.962 c & $28.365 b$ & $0.463 \mathrm{a}$ & $0.514 a$ & $0.416 a$ \\
\hline Moderate & $224.861 \mathrm{~b}$ & $167.322 \mathrm{~b}$ & $342.473 \mathrm{~b}$ & $15.475 b$ & $26.958 \mathrm{~b}$ & $36.417 \mathrm{a}$ & $0.475 a$ & $0.421 \mathrm{~b}$ & $0.405 b$ \\
\hline Severe & $233.387 \mathrm{a}$ & $180.907 \mathrm{a}$ & $349.964 a$ & $16.394 \mathrm{a}$ & $29.314 a$ & $35.156 \mathrm{a}$ & $0.495 \mathrm{a}$ & $0.369 c$ & $0.279 c$ \\
\hline
\end{tabular}

The results are expressed as means $(n=3)$ and different letters in the same column indicate significant difference at the $5 \%$ level.

root pruning at a distance of five or seven times the trunk diameter from the trunk could not optimize the distribution of the root system for regulating the competitive ability of the jujube tree and, thereby, root pruning at a distance of three times the trunk diameter from the trunk would seem to offer the best option.

\section{Acknowledgments}

This work was supported by the National Key Technology R \& D Program of China, Project No. 2006BAD03A1505-3.

\section{References}

[1] Miller S.S., Root pruning and trunk scoring have limited effect on young bearing apple trees, Hortic. Sci. 30 (1995) 981-984.

[2] Gaudet C.L., Keddy P.A., A comparative approach to predicting competitive ability from plant traits, Nature 334 (1988) 242-243.

[3] Bertin C., Yang X.H., Leslle A., Westonl L.A., The role of root exudates and allelochemicals in the rhizosphere, Plant Soil 256 (2003) 67-83.

[4] Kramer P.J., Plant and soil water relationships, McGraw-Hill, N.Y., U.S.A., 1969. 
[5] Passioura K.J., Root and drought resistance, Agric. Water Manag. 7 (1983) 265-280.

[6] Zhang R., Zhang D.Y., A comparative study on root redundancy in spring wheat varieties released in different years in semi-arid area, Chin. J. Plant Ecol. 24 (2000) 298-303.

[7] Miller S.S., Tworkoski T., Regulating vegetative growth in deciduous fruit trees, Plant Growth Regul. Soc. Am. Q. vol. 1 (2003) 8-46.

[8] River T., The miniature fruit garden, Judd $\mathrm{O}$. \& Co., N.Y., U.S.A., 1866.

[9] Geisler D., Ferree D.C., The influence of root pruning on water relations, net photosynthesis and growth of young 'Golden Delicious' apple trees, J. Am. Soc. Hortic. Sci. 109 (1984) 827-831.

[10] Yang S., Xing S., Liu C., Du Z., Wang H., Xu $Y$., Effects of root pruning on the vegetative growth and fruit quality of Zhanhuadongzao trees, Agric. J. 37 (2010) 14-21.

[11] Lu R.K., Analytical methods for soil and agro-chemistry, China Agric. Sci. Technol. Publ. House, Beijing, China, 1999.

[12] Liu C.S., Yang S.X., Agricultural chemistry and analysis, China Agric. Univ. Publ. House, Beijing, China, 1996.

[13] Vysotskaya L.B., Timergalina L.N., Simonyan M.V., Veselov S.Y., Kudoyarova G.R., Growth rate, IAA and cytokinin content of wheat seedling after root pruning, Plant Growth Regul. 33 (2001) 51-57.

[14] Vercammen J., Daele G. van, Gomand A., Root pruning: a valuable alternative to reduce the growth of 'Conference', Italus Hortus 13 (2006) 32-35.

[15] Schupp J.R., Ferree D.C., Influence of time of root pruning on growth, net photosynthesis, and transpiration of young apple trees, Sci. Hortic. 42 (1990) 299-306.
[16] Osaki M., Matsumoto M., Shinano T., Tadano T., A root-shoot interaction hypothesis for high productivity of root crops, Soil Sci. Plant Nutr. 42 (1996) 289-301.

[17] Kharkina T.G., Ottosen C.O., Rosenqvist E., Effects of root restriction on the growth and physiology of cucumber plants, Plant Physiol. 105 (1999) 434-441.

[18] Ma S.C., Xu B.C., LI FM., Liu W.Z., Huang Z.B., Effect of root pruning on competitive ability and water use efficiency in winter wheat, Field Crop. Res. 105 (2008) 56-63.

[19] Pezeshki S.R., Santos M.I., Relationships among oxygen deficiency, root restriction, photosynthesis, and growth in baidcypress (Taxodium distichum L.) seedling, Photosynthetica 35 (1998) 381-390.

[20] Lou C.H., Signal transport and integral behavior in maintaining water economy in higher plant, Chin. Bull. Bot. 17 (2000) 475-477.

[21] Kozlowski T.T., Pallardy S.G., Physiology of woody plants, Acad. Press, San Diego, CA, U.S.A., 1997.

[22] Wu W.H., Plant physiology, China Sci. Press, Beijing, China, 2004.

[23] Blakesley D., Weston G.D., Hall J.F., The role of endogenous IAA in root initiation. I. Evidence from studies on IAA application and analysis of endogenous levels, Plant Growth Regul. 10 (1991) 341-353.

[24] Andersen T., Jensen T.B., Dencker N.L., Effects of root pruning in sour cherry (Prunus cerasus) 'Stevnsbaer', Acta Hortic. 732 (2007) 439-442.

[25] Naser L., Kourosh V., Bahman K., Reza A., Soluble sugars and proline accumulation play a role as effective indices for drought tolerance screening in Persian walnut (Juglans regia L.) during germination, Fruits 65 (2010) 97-112. 


\section{Efecto del tamaño de las raíces en los rendimientos del azufaifo chino.}

Resumen - Introducción. El azufaifo chino presenta siempre ciertos rendimientos desventajosos por el hecho de su crecimiento vegetativo muy vigoroso. Nuestro estudio se llevó a cabo para testear el tamaño de las raíces con el fin de verificar si puede frenar eficazmente el crecimiento vegetativo regulando la competitividad del sistema de raíces para el agua y los nutrientes. Material y métodos. Para nuestro experimento, se cortaron las raíces del azufaifo chino a tres distancias diferentes a partir del tronco (tamaño ligero, moderado y severo de las raíces), a ambos lados entre las filas de azufaifos, a $20 \mathrm{~cm}$ de profundidad. No se tallaron las raíces de los azufaifos testigos. A continuación, hicimos el seguimiento durante tres años de ciertos indicadores de competitividad del azufaifo chino, entre los cuales, la longitud, el número y el grosor de las ramas primarias; las características fotosintéticas y las concentraciones en elementos nutritivos de las hojas; los contenidos de hormonas en lo alto de los árboles, el número de flores y el índice de fructificación, así como el rendimiento y la calidad de los frutos. Resultados y discusión. Al principio, después del tratamiento de las raíces, el tamaño de las raíces indujo que disminuyeran numerosos indicadores, tales como las concentraciones de nitrógeno, fósforo, potasio de las hojas, o la fotosíntesis, la transpiración, la conductancia estomática, la concentración de $\mathrm{CO}_{2}$ intercelular de las hojas, en relación con los mismos indicadores medidos en los árboles del grupo testigo. Con la progresiva emergencia de nuevas raíces, según el tamaño de las mismas, estos índices se comportaron inversamente a los índices medidos en la fase precoz. En comparación con los árboles testigo, el tamaño de las raíces hizo que disminuyeran significativamente la longitud, el número de ramas primarias y el número de flores, pero llevó a un aumento de las ramas primarias, una mejora del índice de fructificación y un aumento de la cantidad de etileno liberado por la corona de los árboles. La calidad de los frutos se mejoró con el tamaño de las raíces: aumento del contenido de vitamina $\mathrm{C}$ y de azúcares totales y disminución de la acidez valorable. El tamaño de las raíces no tuvo efectos en el rendimiento. Deducimos de nuestros resultados que la supresión del sistema de raíces a una distancia del tronco igual a tres veces su diámetro (tamaño severo) es el tratamiento más eficaz para regular la competitividad del sistema de raíces del azufaifo chino.

China / Zizipbus / corta de las raíces / respuesta de la planta / pruebas de rendimiento / características agronómicas / frutas / calidad 